\title{
Phytoplankton Communities Impacted by Thermal Effluents off Two Coastal Nuclear Power Plants in Subtropical Areas of Northern Taiwan
}

\author{
Wen-Tseng Loํㅜ Pei-Kai Hsu ${ }^{1}$, Tien-Hsi Fang ${ }^{2}$, Jian-Hwa Hu ${ }^{2}$, and Hung-Yen Hsieh ${ }^{3,4, *}$ \\ ${ }^{1}$ Institute of Marine Biotechnology and Resources, National Sun Yat-sen University, Kaohsiung, Taiwan, R.O.C. \\ ${ }^{2}$ Department of Marine Environmental Informatics, National Taiwan Ocean University, Keelung, Taiwan, R.O.C. \\ ${ }^{3}$ Graduate Institute of Marine Biology, National Dong Hwa University, Pingtung, Taiwan, R.O.C. \\ ${ }^{4}$ National Museum of Marine Biology and Aquarium, Pingtung, Taiwan, R.O.C.
}

Received 30 December 2014, revised 21 September 2015, accepted 24 September 2015

\begin{abstract}
This study investigates the seasonal and spatial differences in phytoplankton communities in the coastal waters off two nuclear power plants in northern Taiwan in 2009. We identified 144 phytoplankton taxa in our samples, including 127 diatoms, 16 dinoflagellates, and one cyanobacteria. Four diatoms, namely, Thalassionema nitzschioides (T. nitzschioides), Pseudo-nitzschia delicatissima (P. delicatissima), Paralia sulcate (P. sulcata), and Chaetoceros curvisetus (C. curvisetus) and one dinoflagellate Prorocentrum micans (P. micans) were predominant during the study period. Clear seasonal and spatial differences in phytoplankton abundance and species composition were evident in the study area. Generally, a higher mean phytoplankton abundance was observed in the waters off the First Nuclear Power Plant (NPP I) than at the Second Nuclear Power Plant (NPP II). The phytoplankton abundance was usually high in the coastal waters during warm periods and in the offshore waters in winter. The phytoplankton species composition was different in the NPP intake and outlet. An abundant phytoplankton increase in the outlet was frequently detected, probably due to the difference in phytoplankton species suitability to thermal stress. Our results suggest that thermal discharge may affect the phytoplankton communities by altering its species composition within a restricted area close to the NPP. This study provides basic knowledge on phytoplankton distribution patterns, essential information required to further understand the ecological impact caused by thermal effluents.
\end{abstract}

Key words: Phytoplankton, Community composition, Thermal pollution, Nuclear power plants, Coastal waters

Citation: Lo, W. T., P. K. Hsu, T.H. Fang, J. H. Hu, and H. Y. Hsieh, 2016: Phytoplankton communities impacted by thermal effluents off two coastal nuclear power plants in subtropical areas of northern Taiwan. Terr. Atmos. Ocean. Sci., 27, 107-120, doi: 10.3319/TAO.2015.09.24.01(Oc)

\section{INTRODUCTION}

Phytoplankton are the most important primary producer in most marine food webs. Through photosynthesis, phytoplankton convert inorganic compounds into organic compounds using solar energy. Phytoplankton communities are sensitive to environmental variations, and long-term or extreme changes in hydrographic conditions may affect their structure (Cottingham 1999; Li et al. 2011). Seawater temperature plays a critical role in determining the development and maintenance of phytoplankton communities (Davison 1991). The potential impact of thermal discharge from a coastal power plant cooling system on marine organisms and their ecosystem has been studied extensively in the last

\footnotetext{
* Corresponding author

E-mail:hyhsieh@mail.ndhu.edu.tw
}

decades, e.g., bacteria (Choi et al. 2002; Shiah et al. 2006), phytoplankton (Martínez-Arroyo et al. 2000; Poornima et al. 2006; Chuang et al. 2009), zooplankton (Yang et al. 2002; Jiang et al. 2009), crab (Suresh et al. 1995), fish (Teixeira et al. 2009), and sedentary organisms (Lardicci et al. 1999; Teixeira et al. 2009). Most recent impact studies on phytoplankton focused mainly on the effects of elevated seawater temperature and residual chlorine on the biomass and productivity (Poornima et al. 2005; Rajadurai et al. 2005; Chuang et al. 2009). Li et al. (2011) reported that the nuclear power plant thermal discharge in the subtropical Daya Bay in China strongly influenced the phytoplankton community. Here, a remarkable shift from diatoms to dinoflagellates was observed when the seawater temperature reached $35^{\circ} \mathrm{C}$ or $>3.7^{\circ} \mathrm{C}$ relative to the normal ambient temperature in the study area. 
The waters off the First (NPP I) and Second (NPP II) Nuclear Power Plants are located at the southern margin of the East China Sea (ECS). The succession of water masses in this area is controlled mainly by monsoon systems (Liu et al. 1992; Jan et al. 2006). In summer the southwesterly monsoon prevails and makes the South China Sea Surface Current (SCSSC) flow northwards through the Taiwan Strait to the southern ECS. In winter the northeasterly monsoon usually drives the cold, low-saline, nutrient-rich China Coastal Current (CCC) southwards along the coast of mainland China into the northern and central Taiwan Strait, where it also inhibits the northward intrusion of the SCSSC. The intrusion of the Kuroshio Current to the southern ECS shelf is year-round.

Studies on the thermal discharge from NPP I and NPP II into the coastal waters of northern Taiwan are available (Hung et al. 1998; Shiah et al. 2005, 2006). Lo et al. (2004) investigated the spatio-temporal distributions of phytoplankton and found that there were no significant differences in phytoplankton communities between the NPP outlet and intake regions. Shiah et al. (2005) explored planktonic and ecosystem responses to thermal effluents from NPP II and suggested that the phytoplankton were more vulnerable than heterotrophs to thermal stress in temperature manipulation experiments. Similarly, chlorination caused a greater reduction in phytoplankton productivity than in periphyton productivity compared to elevated seawater temperatures near NPP II (Chuang et al. 2009). The present study was carried out in the coastal waters off NNP I and NNP II in northern
Taiwan. The objectives of this study were (1) to compare the abundance and communities of phytoplankton between the NPP outlet and intake regions in subtropical Taiwan, and (2) determine the potential effect of thermal discharges on phytoplankton communities located at the NPP outlets.

\section{MATERIAL AND METHODS}

\subsection{Study Area}

NPP I and NPP II are located in Jinshan and Wanli, respectively, of northern Taiwan. The two power plants use $35 \mathrm{~m}^{3} \mathrm{~s}^{-1}$ (NPP I) and $44 \mathrm{~m}^{3} \mathrm{~s}^{-1}$ (NPP II) of seawater for cooling. In general the surface seawater temperature in the intake region ranges from $18^{\circ} \mathrm{C}$ in winter to $30^{\circ} \mathrm{C}$ in summer. A temperature gradient of $8-12^{\circ} \mathrm{C}$ at the surface characterizes the outlet region water column. The area that could be affected by a thermal plume should be inside the $500-1000 \mathrm{~m}$ range away from the outlet. NPP I faces the open ocean in the study area, while NPP II is located within semi-enclosed Kuosheng Bay (Fig. 1). Kuosheng Bay has a $8 \mathrm{~km}^{2}$ surface area with a mean depth of $15 \mathrm{~m}$. The seawater exchange rate between the inshore and offshore areas is lower near NPP II than NPP I and this difference may affect the thermal effluent dispersion efficiency.

\subsection{Sampling}

The R/V Ocean Research II was commissioned to collect phytoplankton samples during the months of January

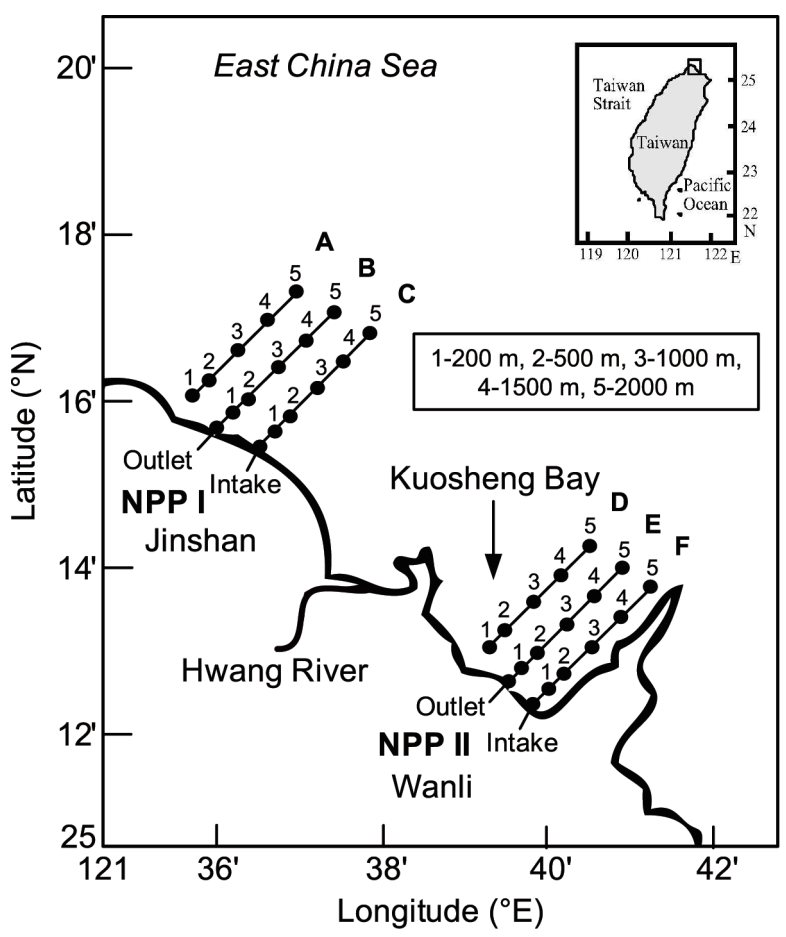

Fig. 1. Sampling stations in the waters of the First (NPP I) and Second (NPP II) Nuclear Power Plants in northern Taiwan in 2009. 
(winter), April (spring), July (summer), and October (autumn) in 2009. The velocity and direction of the waters in the study area were measured in situ using the Acoustic Doppler Current Profiler (ADCP, Teledyne RD Instruments). There were 30 sampling stations in 6 transects, with each track containing 5 stations at 250, 500, 1000, 1500 , and $2000 \mathrm{~m}$, respectively, offshore and 4 sampling stations near the NPP outlets and intakes (Fig. 1). At each sampling station except for the outlet and intake, sea surface temperatures (SSTs) and salinity were recorded with a General Oceanic's SeaBird CTD (SBE-911 Plus). Water samples for phytoplankton identification and chlorophyll $a$ $(\mathrm{Chl} a)$ and nutrient measurements (phosphate, silicate, nitrite, and nitrate) were collected at $1-2 \mathrm{~m}$ depth using GoFlo bottles. Of these waters, to each $500 \mathrm{~mL}$ water sample for phytoplankton identification $25 \mathrm{~mL}$ of borax-buffered formalin were added for preservation. Chl $a$ samples were collected in situ by filtering $100 \mathrm{~mL}$ water through $\mathrm{GF} / \mathrm{F}$ filters that were frozen under dark conditions over as little time as possible before laboratory analyses. The remaining water samples (four liters of each sample) were stored in a polyethylene bottle at $4^{\circ} \mathrm{C}$ and returned to the laboratory for further quantitative filtration and analyses.

In the laboratory, for $\mathrm{Chl} a$, the filter collected on board was placed in a $15 \mathrm{~mL}$ centrifuge tube with $10 \mathrm{~mL}$ $90 \%$ acetone. After vigorous vortexing, the pigments were extracted in complete darkness for $20 \mathrm{~h}$ (Strickland and Parsons 1972; Lobban et al. 1988). The tubes were then centrifuged at $1000 \times \mathrm{g}$ for $15 \mathrm{~min}$ and the supernatant was transferred into a fluorometer cell. The $\mathrm{Chl} a$ concentration in the supernatant was measured with a fluorometer (Turner Design 10-AU). In accordance with Bruland et al. (2005), $10 \mu \mathrm{g} \mathrm{L}^{-1} \mathrm{Chl} a$ was set as the baseline value above which an algal bloom was projected to occur. A part of each remaining water sample was filtered through pre-combusted GF/F filters (at $450^{\circ} \mathrm{C}, 4 \mathrm{~h}$ ). The filtered water was used to measure nitrate, nitrite, phosphate, and silicate. Three replicate measurements were made for each chemical analysis. The four parameters were determined colorimetrically (Grasshoff et al. 1983) equipped with a flow injection analysis. Spiked nutrients recovery in oligotrophic Kuroshio surface water was better than $95 \%$.

The phytoplankton samples were shaken to ensure homogeneity and, thereafter, a $1 \mathrm{~mL}$ sample was concentrated from $100-250 \mathrm{~mL}$ of the shaken water sample by sedimentation for $24 \mathrm{~h}$ in a Combined Plate Chamber (Hydro-Bios). All phytoplankton cells in the concentrated sample were identified and counted with an inverted microscope (NikonA300) at 200 or 400 magnification. The size of the smallest cells recorded in the present study was about $2 \mu \mathrm{m}$. Each specimen was identified to species level whenever possible. The phytoplankton abundance was expressed as the number of cells per liter. All of the phytoplankton samples were analyzed within two months after each sampling cruise.

\subsection{Data Analysis}

The Shannon-Weaver diversity index $\left(H^{\prime}\right.$; Shannon and Weaver 1963) was used to calculate the phytoplankton species diversity. The Sørensen similarity index (SI; Sørensen 1948) was used to compare the phytoplankton similarity between outlet and intake stations. Similarity was calculated by analyzing the similarity of pairs taken from sites in terms of the presence or absence of specific species. Seasonal hydrographic and biological features based on the data collected at each sampling station (including SSTs, salinity, and $\mathrm{Chl} a$ ) were characterized using principal component analysis (PCA; Pielou 1984). The differences in 6 hydrographic variables (temperature, salinity, phosphate, silicate, nitrite, and nitrate), $\mathrm{Chl} a$, and abundance, species richness, and $H^{\prime}$ values for phytoplankton between NPPs and between seasons were tested using one-way ANOVA (Dunn and Clark 1974). In order to examine the spatial and temporal differences in community structure, non-metric multidimensional scaling (MDS; Cox and Cox 1994), ordination using the Euclidean distance based on similarity matrix of $\log (x+1)$-transformed abundance of phytoplankton was performed with the PRIMER-6 software package. A one-way analysis of similarities (ANOSIM; Clarke and Warwick 2001) was applied to evaluate the effects of location and season on the phytoplankton community composition. This procedure compares the average rank similarities within pre-defined groups of samples with the average similarity between groups. If the global test results indicated significances at the 5\% probability level, pairwise $R$ values were used to determine their separation. An $R$ value close to 1 indicates a strong separation between groups, while an $R$ value of 0 indicates no difference between groups. The relationships between phytoplankton abundances and environmental variables were analyzed using multiple regressions with the forward stepwise method (Allison 1998).

\section{RESULTS}

\subsection{Hydrographic Features and $\mathrm{Chl} a$ Concentration}

Throughout the study period, surface temperature fluctuated from $17.71-28.64^{\circ} \mathrm{C}$, salinity from $33.16-34.39$, phosphate from 0.28 - $16.24 \mu \mathrm{g} \mathrm{L}^{-1}$, nitrate from 4.42 $121.23 \mu \mathrm{g} \mathrm{L}^{-1}$, nitrite from $0.84-16.33 \mu \mathrm{g} \mathrm{L}^{-1}$, silicate from 70.42 - $593.46 \mu \mathrm{g} \mathrm{L}^{-1}$, and Chl $a$ from 0.27 - $1.14 \mu \mathrm{g} \mathrm{L}^{-1}$. The SSTs and Chl $a$ showed similar seasonal patterns in the waters off NPP I and NPP II. The highest SSTs and Chl $a$ concentrations were recorded in summer and the lowest SSTs and Chl $a$ concentrations were recorded in winter and autumn (Figs. 2a, c). An opposite trend was observed in nutrients, with the highest values generally noted in autumn or winter and lowest values in summer (Figs. 2d - g). Although no significant difference was monitored in hydrographic and biological variables between NPP I and NPP II, except 

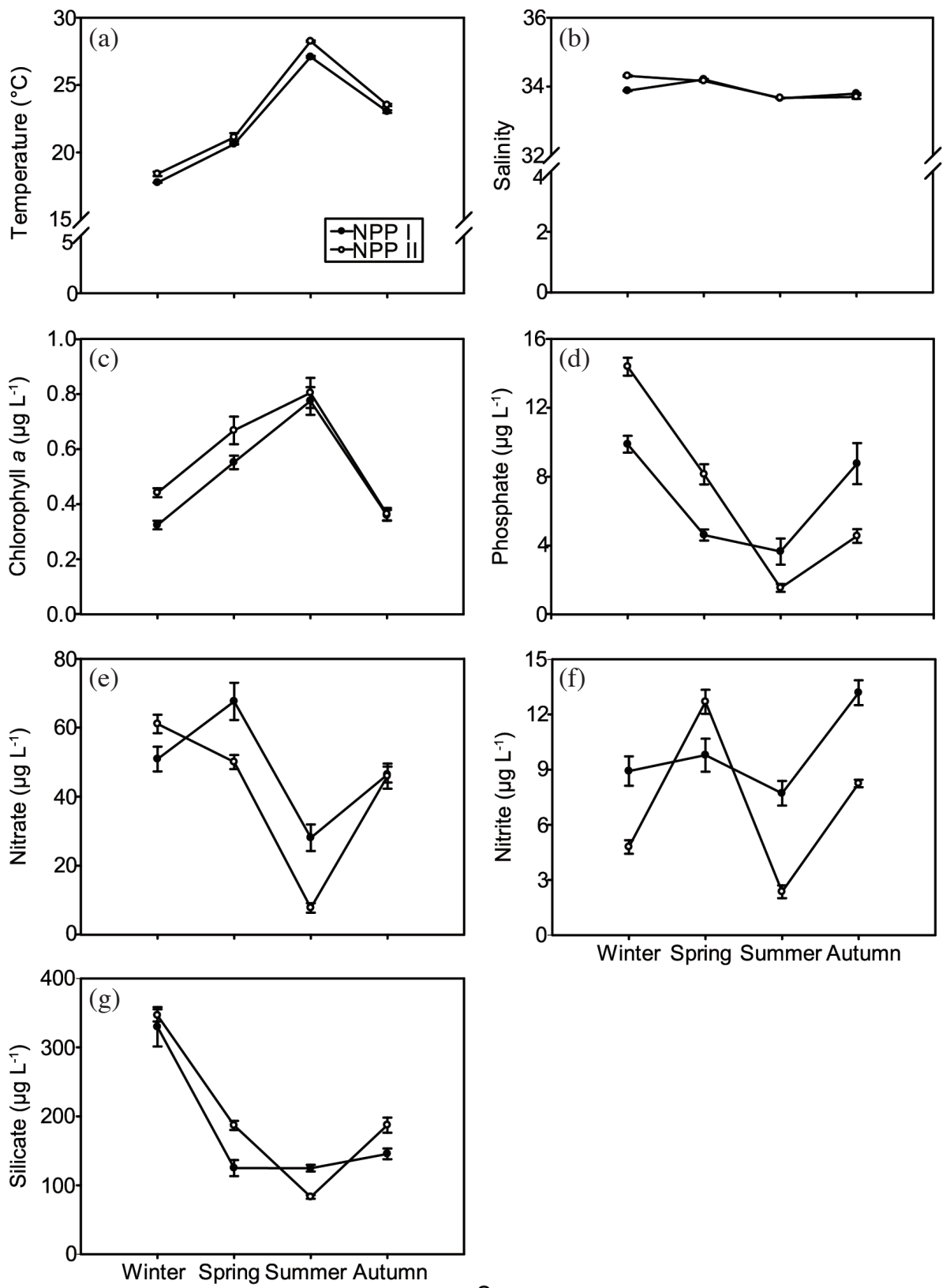

Season

Fig. 2. Seasonal variations in temperature (a), salinity (b), Chl $a$ (c), phosphate (d), nitrate (e), nitrite (f), and silicate (g) in the waters of the NPP I and NPP II in northern Taiwan in 2009.

for nitrite, slightly higher temperatures were generally observed in the waters off NPP II (Fig. 2). The nitrite was usually higher near NPP I than near NPP II (one-way ANOVA, $\left.F_{1,96}=14.008, P<0.001\right)$.

Four significantly seasonal station groups were distinguished in the PCA result based on SSTs, salinity and Chl $a$ (Fig. 3). The principal components 1 and 2 could explain 66.9 and $28.5 \%$ of the variations, respectively. Seawater temperature was the most important factor that determines the ordination of all sampling stations. Current velocities in the waters at NPP I were generally higher than those at NPP II (Fig. 4). In the NPP I waters the currents flowed mainly eastward or south-eastward during high tide. Conversely, they flowed north-westward or northward and sometimes in cycles during low tide. In the NPP II waters the currents flowed mainly eastward during high tide and westward during low tide.

\subsection{Phytoplankton Abundance and Diversity}

A total of 144 phytoplankton taxa (127 diatoms, 16 dinoflagellates, and one cyanobacteria) were identified. The highest number of taxa was recorded in summer (102) and the lowest in spring (56) (Table 1). The overall mean abundance 
$( \pm \mathrm{SE})$ was $2457 \pm 145$ cells $\mathrm{L}^{-1}$. A seasonal difference in phytoplankton abundance (one-way ANOVA, $F_{3,136}=7.631$, $P<0.001)$ was evident in the study area, with the highest abundances in winter and spring, moderate abundance in summer, and lowest abundance in autumn. No significant seasonal differences in species richness (one-way ANOVA, $F_{3,136}=1.436, P>0.05$ ) and species diversity (one-way ANOVA, $\left.F_{3,136}=1.506, P>0.05\right)$ could be observed (Table 1 ). In general, the mean phytoplankton abundance and species richness were higher in the waters off NPP I than off NPP II, except for autumn. Meanwhile, the seasonal mean abundance and species richness for phytoplankton in the
NPP outlets were higher in spring and autumn, particularly in spring, and lower in winter and summer (Table 1). Phytoplankton abundance in coastal waters was usually higher ( $<500 \mathrm{~m}$ offshore) from spring to autumn and offshore in winter, respectively (Fig. 5).

\subsection{Phytoplankton Community Composition}

The diatom Thalassionema nitzschioides ( $T$. nitzschioides) (Grunow) Mereschkowsky 1902, constituted $22.26 \%$ of the total phytoplankton abundance. This was the most abundant species during the entire survey, followed

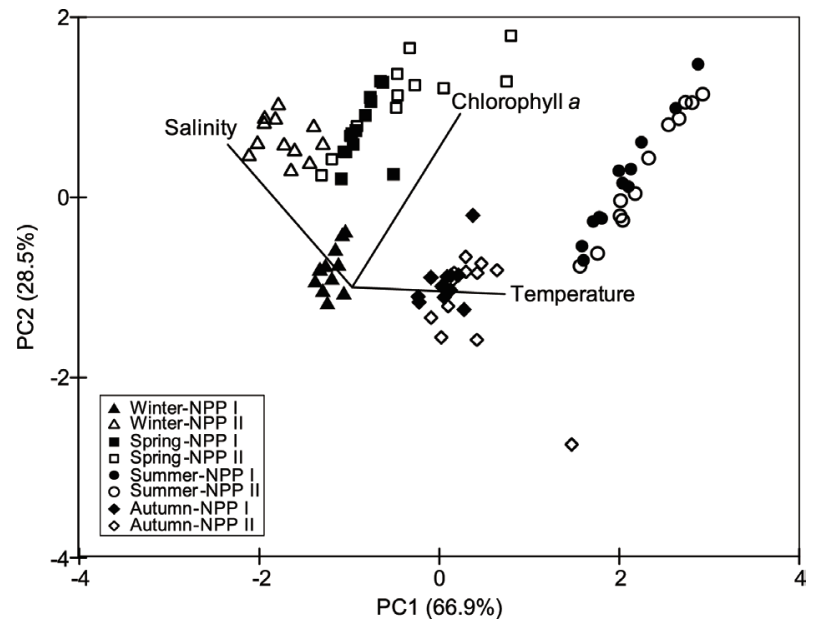

Fig. 3. Ordination diagram of PCA based on seawater surface temperature, salinity and Chl $a$ concentration at sampling stations.
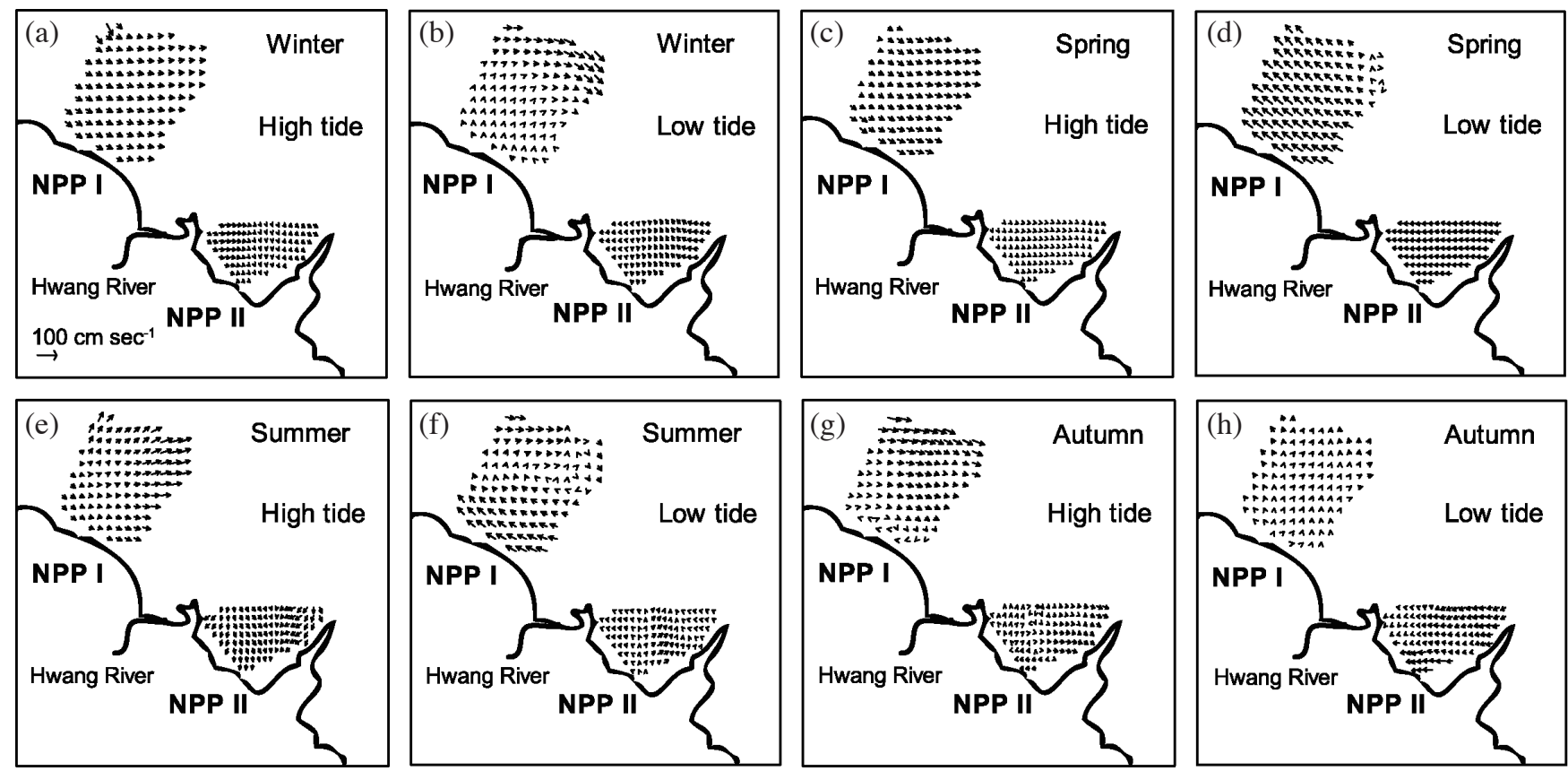

Fig. 4. Current direction and velocity in the NPP I and NPP II waters during the survey periods. Data measured by ADCP (Acoustic Doppler Current Profiler, Teledyne RD Instruments) 
Table 1. Mean abundance $\left( \pm \mathrm{SE}\right.$, cells $\left.\mathrm{L}^{-1}\right)$, species richness, and species diversity index of phytoplankton and the season effect tested using one-way ANOVA in the waters at the First (NPP I) and Second (NPP II) Nuclear Power Plants in 2009.

\begin{tabular}{|c|c|c|c|c|c|}
\hline Season & Winter & Spring & Summer & Autumn & one-way ANOVA \\
\hline \multirow{7}{*}{ Abundance } & M: $3080 \pm 269$ & M: $3012 \pm 490$ & M: $2247 \pm 333$ & M: $1484 \pm 216$ & $P<0.001$ \\
\hline & M1: $3355 \pm 427$ & M1: $3633 \pm 547$ & M1: $2692 \pm 240$ & M1: $1358 \pm 125$ & - \\
\hline & M2: $2805 \pm 326$ & M2: $2391 \pm 384$ & M2: $1802 \pm 382$ & M2: $1609 \pm 418$ & - \\
\hline & I1: 2240 & I1: 5840 & I1: 3640 & I1: 2360 & - \\
\hline & I2: 2480 & I2: 1120 & I2: 3320 & I2: 1640 & - \\
\hline & O1: 1280 & O1: 8080 & O1: 2440 & O1: 2120 & - \\
\hline & O2: 1760 & O2: 7280 & O2: 1480 & $\mathrm{O} 2: 2200$ & - \\
\hline \multirow{8}{*}{ Species richness } & Total: 80 & Total: 56 & Total: 102 & Total: 76 & $P>0.05$ \\
\hline & M: $9 \pm 0$ & M: $9 \pm 1$ & M: $10 \pm 1$ & M: $9 \pm 0$ & - \\
\hline & M1: $9 \pm 1$ & M1: $9 \pm 1$ & M1: $12 \pm 1$ & M1: $9 \pm 1$ & - \\
\hline & $\mathrm{M} 2: 8 \pm 1$ & $\mathrm{M} 2: 9 \pm 1$ & $\mathrm{M} 2: 8 \pm 1$ & M2: $9 \pm 1$ & - \\
\hline & I1: 6 & I1: 11 & I1: 16 & I1: 16 & - \\
\hline & I2: 6 & I2: 9 & I2: 13 & I2: 11 & - \\
\hline & O1: 8 & O1: 15 & O1: 10 & O1: 11 & - \\
\hline & $\mathrm{O} 2: 8$ & O2: 20 & O2: 11 & O2: 10 & - \\
\hline \multirow{7}{*}{ Species diversity index } & M: $2.52 \pm 0.06$ & M: $2.69 \pm 0.10$ & M: $2.68 \pm 0.12$ & M: $2.56 \pm 0.06$ & $P>0.05$ \\
\hline & M1: $2.51 \pm 0.09$ & M1: $2.68 \pm 0.08$ & M1: $2.84 \pm 0.12$ & M1: $2.52 \pm 0.10$ & - \\
\hline & M2: $2.52 \pm 0.09$ & $\mathrm{M} 2: 2.69 \pm 0.12$ & $\mathrm{M} 2: 2.52 \pm 0.10$ & $\mathrm{M} 2: 2.61 \pm 0.07$ & - \\
\hline & I1: 2.10 & I1: 2.84 & I1: 3.43 & I1: 3.41 & - \\
\hline & I2: 2.06 & I2: 2.95 & I2: 2.94 & I2: 3.03 & - \\
\hline & O1: 2.66 & O1: 3.27 & O1: 3.05 & O1: 2.78 & - \\
\hline & $\mathrm{O} 2: 2.64$ & $\mathrm{O} 2: 3.63$ & $\mathrm{O} 2: 3.15$ & $\mathrm{O} 2: 2.50$ & - \\
\hline
\end{tabular}

Note: $M$, the average of all stations; $M 1$ and M2, the average of all NPP I or NPP II stations; II and I2, the intakes of NPP I and NPP II; $\mathrm{O} 1$ and $\mathrm{O} 2$, the NPP I and NPP II outlets.
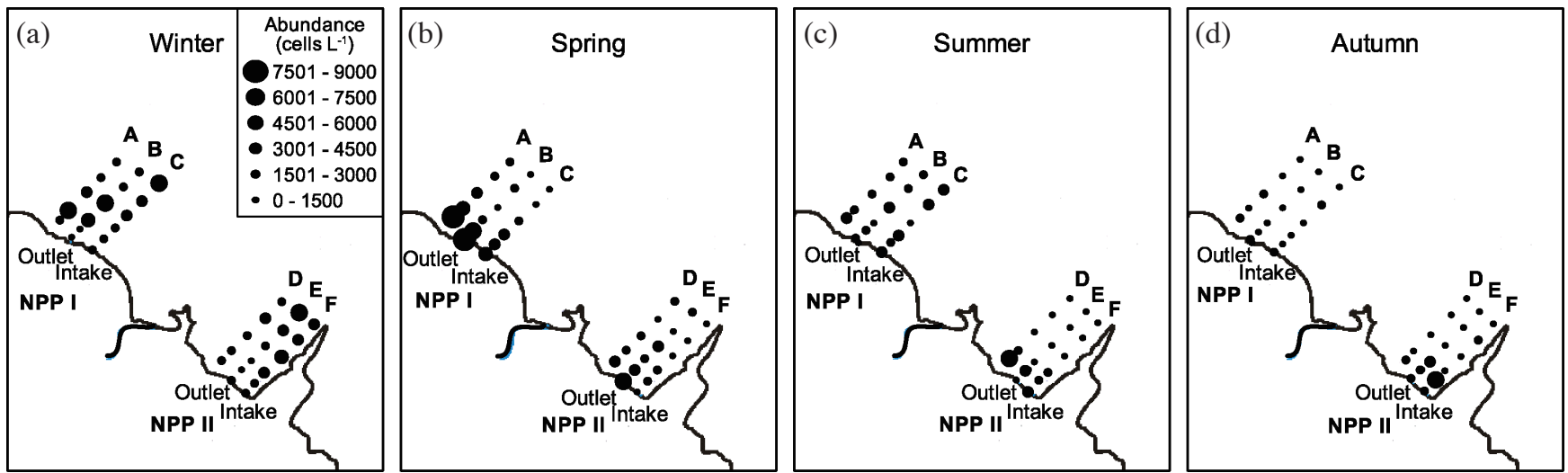

Fig. 5. Abundance patterns of phytoplankton in the waters off NPP I and NPP II in northern Taiwan in 2009.

by the diatoms Pseudo-nitzschia delicatissima (P. delicatissima) (Cleve) Heiden 1928 (6.63\%) and Paralia sulcata $(P$. sulcata) (Ehrenberg) Cleve 1873 (4.63\%), the dinoflagellate Prorocentrum micans (P.micans) Ehrenberg 1834 (4.61\%), and the diatom Chaetoceros curvisetus (C. curvisetus)
Cleve $1889(4.44 \%)$. The abundance of the five dominant phytoplankton species showed different seasonal fluctuations (Fig. 6). The ANOSIM results showed significant temporal and spatial differences in the phytoplankton community. Phytoplankton communities differed significantly 
between the NPPs (Global $R=0.06, P<0.01$ ). Although the station groups overlapped partially, a seasonal pattern, particularly between winter and summer, became evident as well (Global $R=0.22, P<0.01$; Fig. 7). Among the dominant species (Table 2), one species, T. nitzschioides, was recorded abundantly during all seasons. Two diatoms were found during three seasons: Chaetoceros compressus (C. compressus) Lauder 1864 (in winter, summer, and autumn) and $P$. delicatissima (in spring, summer, and autumn). Four were recorded in two seasons: the diatom $P$. sulcata (in winter and spring), Melosira moniliformis (M. moniliformis) (O. F. Müller) C. Agardh 1824 (in spring and autumn), and Thalassionema frauenfeldii (T. frauenfeldii) (Grunow) Tempère and Peragallo 1910 (in winter and summer), and the dinoflagellate $P$. micans (in spring and summer). Most uniquely, several taxa were highly abundant during a specific season: the diatom C. curvisetus $(12.45 \%)$ in winter, Nitzschia frigida Grunow 1880 (5.27\%) in summer, and Rhabdonema arcuatum (R. arcuatum) (Lyngbye) Kützing 1844 (4.12\%) in autumn. Except for some common
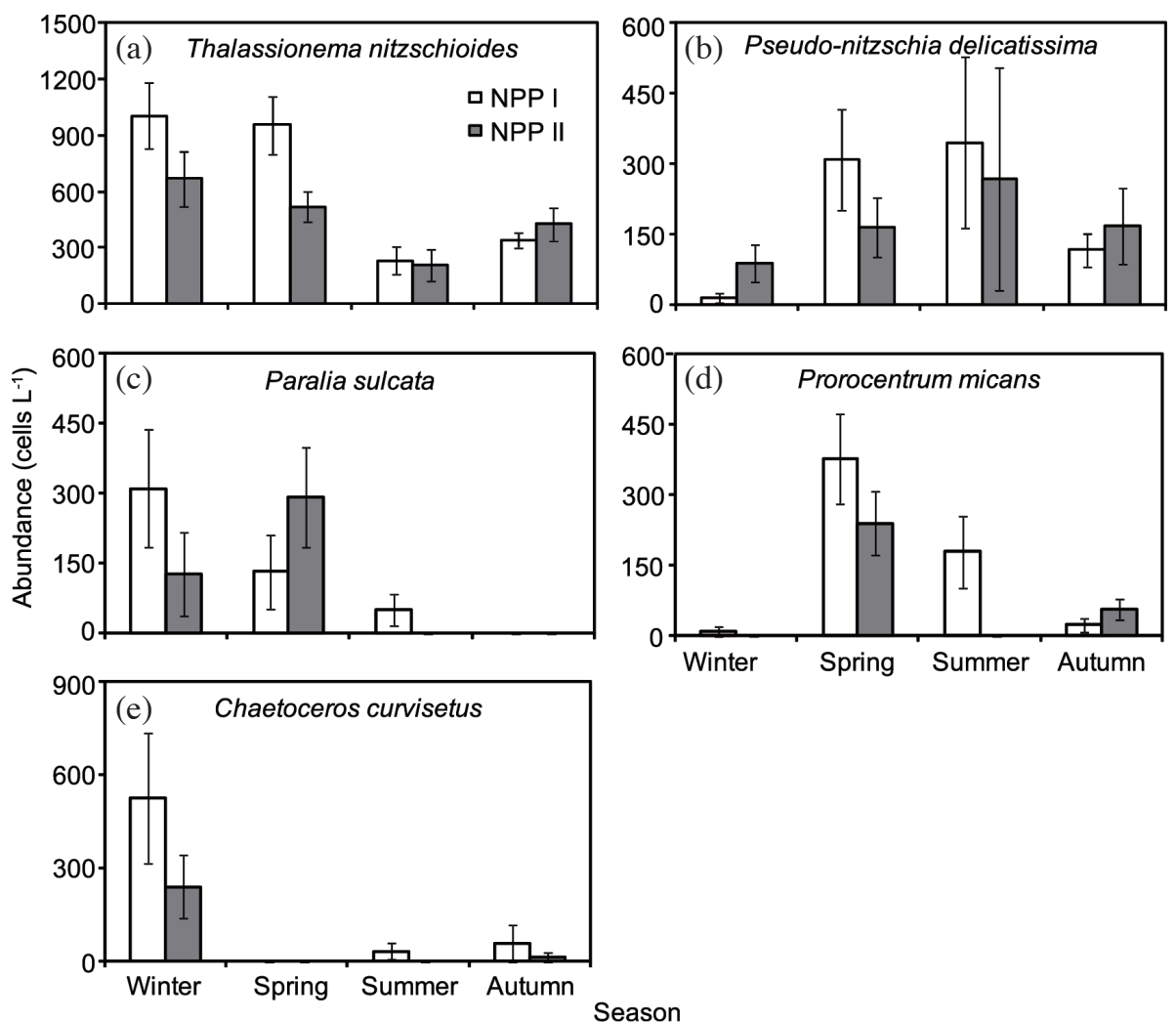

Fig. 6. Seasonal changes in abundance of the five dominant phytoplankton species in the waters off NPP I and NPP II in northern Taiwan in 2009.

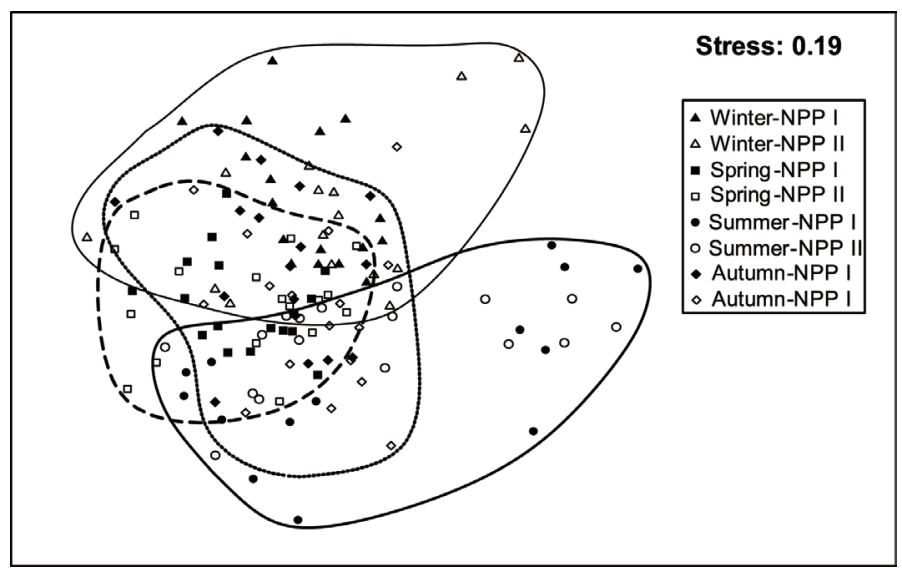

Fig. 7. MDS ordination using the Euclidean distance based on similarity matrix of $\log (x+1)$-transformed abundance of phytoplankton in 2009. 
Table 2. Composition of the dominant phytoplankton species in the NPP I and NPP II waters in 2009. The mean abundance $\left( \pm \mathrm{SE}\right.$, cells $\left.\mathrm{L}^{-1}\right)$ and relative abundance $(\mathrm{RA}, \%)$ also shown.

\begin{tabular}{|c|c|c|c|c|c|}
\hline \multicolumn{3}{|l|}{ NPP I } & \multicolumn{3}{|l|}{ NPP II } \\
\hline Winter & Mean & RA & Winter & Mean \pm SE & $\mathbf{R A}$ \\
\hline Thalassionema nitzschioides ${ }^{4}$ & $1002 \pm 177$ & 29.87 & Thalassionema nitzschioides ${ }^{4}$ & $668 \pm 146$ & 23.83 \\
\hline Chaetoceros curvisetus $^{1}$ & $527 \pm 209$ & 15.71 & Chaetoceros curvisetus $^{1}$ & $240 \pm 102$ & 8.56 \\
\hline Paralia sulcata $^{2}$ & $311 \pm 127$ & 9.26 & Chaetoceros compressus $^{3}$ & $212 \pm 91$ & 7.55 \\
\hline Thalassionema frauenfeldii ${ }^{2}$ & $122 \pm 25$ & 3.65 & Chaetoceros didymus ${ }^{1}$ & $151 \pm 78$ & 5.37 \\
\hline Lauderia borealis $^{1}$ & $118 \pm 34$ & 3.51 & Paralia sulcata $^{2}$ & $127 \pm 90$ & 4.53 \\
\hline Spring & Mean \pm SE & RA & Spring & Mean \pm SE & $\mathbf{R A}$ \\
\hline Thalassionema nitzschioides ${ }^{4}$ & $955 \pm 154$ & 26.30 & Thalassionema nitzschioides ${ }^{4}$ & $518 \pm 80$ & 21.65 \\
\hline Prorocentrum micans ${ }^{2}$ & $376 \pm 95$ & 10.36 & Paralia sulcata $^{2}$ & $292 \pm 108$ & 12.20 \\
\hline Melosira moniliformis ${ }^{2}$ & $334 \pm 127$ & 9.20 & Prorocentrum micans ${ }^{2}$ & $240 \pm 68$ & 10.04 \\
\hline Pseudo-nitzschia delicatissima ${ }^{3}$ & $311 \pm 107$ & 8.55 & Pseudo-nitzschia delicatissima ${ }^{3}$ & $165 \pm 63$ & 6.89 \\
\hline Bacillaria paradoxa ${ }^{1}$ & $174 \pm 110$ & 4.79 & Leptocylindrus danicus ${ }^{2}$ & $155 \pm 155$ & 6.50 \\
\hline Summer & Mean $\pm \mathrm{SE}$ & $\mathbf{R A}$ & Summer & Mean \pm SE & $\mathbf{R A}$ \\
\hline Pseudo-nitzschia delicatissima ${ }^{3}$ & $346 \pm 182$ & 12.85 & Pseudo-nitzschia delicatissima ${ }^{3}$ & $268 \pm 237$ & 14.88 \\
\hline Thalassionema nitzschioides ${ }^{4}$ & $233 \pm 77$ & 8.65 & Chaetoceros compressus $^{3}$ & $240 \pm 68$ & 13.32 \\
\hline Chaetoceros compressus ${ }^{3}$ & $226 \pm 58$ & 8.39 & Thalassionema nitzschioides ${ }^{4}$ & $207 \pm 84$ & 11.49 \\
\hline Prorocentrum micans ${ }^{2}$ & $179 \pm 76$ & 6.64 & Thalassionema frauenfeldii ${ }^{2}$ & $151 \pm 50$ & 8.36 \\
\hline Asterionella japonica $^{1}$ & $118 \pm 88$ & 4.37 & Nitzschia frigida $^{1}$ & $136 \pm 75$ & 7.57 \\
\hline Autumn & Mean \pm SE & $\mathbf{R A}$ & Autumn & Mean \pm SE & $\mathbf{R A}$ \\
\hline Thalassionema nitzschioides ${ }^{4}$ & $341 \pm 39$ & 25.13 & Thalassionema nitzschioides ${ }^{4}$ & $426 \pm 90$ & 26.46 \\
\hline Pseudo-nitzschia delicatissima ${ }^{3}$ & $118 \pm 35$ & 8.67 & Pseudo-nitzschia delicatissima ${ }^{3}$ & $167 \pm 81$ & 10.38 \\
\hline Rhabdonema arcuatum $^{1}$ & $96 \pm 66$ & 7.11 & Melosira moniliformis ${ }^{2}$ & $106 \pm 106$ & 6.58 \\
\hline Rhizosolenia stolterfothii ${ }^{1}$ & $80 \pm 45$ & 5.89 & Chaetoceros compressus $^{3}$ & $94 \pm 69$ & 5.85 \\
\hline Tropidoneis lepidoptera ${ }^{1}$ & $68 \pm 21$ & 5.03 & Leptocylindrus danicus ${ }^{2}$ & $56 \pm 43$ & 3.51 \\
\hline
\end{tabular}

Note: 1: Denote the species occurring in any one season; 2: denote the species occurring in any two seasons; 3 : denote the species occurring in any three seasons; 4 : denote the species occurring in all seasons.

species, for example T. nitzschioides, $T$. frauenfeldii, and $P$. delicatissima, the dominant phytoplankton species compositions in the outlet and intake regions of NPPs were different (Table 3). The similarity indices were $0-54 \%$ at NPP I and $29-42 \%$ at NPP II between the outlet and intake during different sampling periods.

\subsection{Relationships Between the Dominant Phytoplankton and Environmental Variables}

The abundances of the five dominant phytoplankton species were significantly correlated to environmental variables. The predictive equations derived from stepwise regression are shown in Table 4. The abundance of T. nitzschioides correlated significantly negative with temperature and positively to nitrite. The abundance of $P$. delicatissima showed positive correlations with temperature and nitrate, while $P$. sulcata was significantly positively correlated to nitrate. The abundances of $P$. micans and total phytoplank- ton were positively correlated to salinity. The abundances of C. curvisetus and total phytoplankton were positively correlated to silicate. Species richness and species diversity had no correlations with any one environmental variable.

\section{DISCUSSION}

\subsection{Phytoplankton Community Structure}

Seawater temperature (Jordan et al. 1983; Li et al. 2011), salinity (Heip et al. 1995), and available nutrients (Hecky and Kilham 1988) are important determining factors that structure phytoplankton communities. Moreover, these factors are further affected by local oceanographic characteristics. In this study significantly higher nutrients were observed during the cold periods (Figs. 2d - g), probably due to the intrusion of the CCC. However, in addition to mesoscale oceanographic features, the local topographic conditions might have played an important role as well. NPP I faces the open ocean while NPP II is located within a 
Table 3. Abundances (cells L-1) of dominant phytoplankton species at the outlet and intake of the NPP I and NPP II in 2009.

\begin{tabular}{|c|c|c|c|c|c|c|c|}
\hline \multicolumn{4}{|c|}{ NPP I } & \multicolumn{4}{|c|}{ NPP II } \\
\hline Winter & Outlet & Winter & Intake & Winter & Outlet & Winter & Intake \\
\hline Thalassionema nitzschioides & 480 & Thalassionema nitzschioides & 1120 & Thalassionema nitzschioides & 560 & Chaetoceros didymus & 960 \\
\hline Thalassionema frauenfeldii & 160 & Grammatophora marina & 400 & Tropidoneis lepidoptera & 400 & Thalassionema nitzschioides & 880 \\
\hline Rhicosphenia curvata & 160 & Thalassiosira decipiens & 240 & Navicula directa & 240 & Asterionella kariana & 240 \\
\hline Striatella delicatula & 160 & Thalassionema frauenfeldii & 160 & Thalassionema frauenfeldii & 160 & Thalassiosira decipiens & 160 \\
\hline Fragilaria striatula & 80 & Tropidoneis lepidoptera & 160 & Pleurosigma intermedium & 160 & Asteromphalus heptactis & 160 \\
\hline Spring & Outlet & Spring & Outlet & Spring & Outlet & Spring & Outlet \\
\hline Prorocentrum micans & 1680 & Thalassionema nitzschioides & 2160 & Thalassionema nitzschioides & 1600 & Thalassionema nitzschioides & 320 \\
\hline Thalassionema nitzschioides & 1520 & Campylosira cymbelliformis & 720 & $\begin{array}{l}\text { Pseudo-nitzschia } \\
\text { delicatissima }\end{array}$ & 1040 & Pleurosigma intermedium & 160 \\
\hline Melosira monilifonnis & 960 & Nitzschia seriata & 720 & Prorocentrum micans & 1040 & Nitzschia sigma & 160 \\
\hline Rhabdonema arcuatum & 960 & Melosira sulcata & 480 & Tropidoneis lepidoptera & 720 & Prorocentrum micans & 80 \\
\hline Leptocylindrus danicus & 800 & Melosira monilifonnis & 480 & Melosira monilifonnis & 560 & Thalassionema frauenfeldii & 80 \\
\hline Summer & Outlet & Summer & Outlet & Summer & Outlet & Summer & Outlet \\
\hline Thalassionema nitzschioides & 480 & Nitzschia longissima & 640 & $\begin{array}{c}\text { Pseudo-nitzschia delicatis- } \\
\text { sima }\end{array}$ & 360 & $\begin{array}{l}\text { Pseudo-nitzschia } \\
\text { delicatissima }\end{array}$ & 1000 \\
\hline Rhizosolenia stolterfothii & 440 & Rhabdonema arcuatum & 520 & $\begin{array}{c}\text { Rhizosolenia imbricata } v . \\
\text { shrubsolei }\end{array}$ & 240 & Thalassionema nitzschioides & 640 \\
\hline Rhizosolenia delicatula & 360 & Guinardia flaccida & 440 & Thalassionema nitzschioides & 160 & Leptocylindrus danicus & 600 \\
\hline $\begin{array}{l}\text { Pseudo-nitzschia } \\
\text { delicatissima }\end{array}$ & 320 & Grammatophora hamulifera & 440 & Prorocentrum micans & 160 & Licmophora abbreviata & 240 \\
\hline Prorocentrum micans & 280 & Prorocentrum minimun & 400 & Ceratium furca & 160 & Prorocentrum gracile & 200 \\
\hline Autumn & Outlet & Autumn & Outlet & Autumn & Outlet & Autumn & Outlet \\
\hline Rhabdonema arcuatum & 880 & Thalassionema nitzschioides & 520 & Thalassionema nitzschioides & 920 & Campylosira cymbelliformis & 440 \\
\hline Tropidoneis lepidoptera & 280 & Chaetoceros compressus & 440 & Coscinodiscus excentricus & 480 & Thalassionema nitzschioides & 360 \\
\hline Thalassionema nitzschioides & 200 & $\begin{array}{l}\text { Pseudo-nitzschia } \\
\text { delicatissima }\end{array}$ & 320 & Skeletonema costatum & 280 & Coscinodiscus excentricus & 160 \\
\hline Pleurosigma intermedium & 160 & Fragilaria striatula & 240 & Campylosira cymbelliformis & 160 & Thalassiosira decipiens & 160 \\
\hline Biddulphia aurita & 160 & Lauderia borealis & 120 & Fragilaria striatula & 80 & Prorocentrum micans & 120 \\
\hline
\end{tabular}

Table 4. Stepwise regression and partial correlation coefficient $(R)$ results evaluating the relationships between the five dominant phytoplankton species abundances and environmental variables in the NPP I and NPP II waters in 2009.

\begin{tabular}{c|ccccccc}
\hline & $\boldsymbol{R}$ for $\mathbf{T}$ & $\boldsymbol{R}$ for $\mathbf{S}$ & $\boldsymbol{R}$ for $\mathbf{P}$ & $\boldsymbol{R}$ for $\mathbf{N}_{\mathbf{1}}$ & $\boldsymbol{R}$ for $\mathbf{N}_{\mathbf{2}}$ & $\boldsymbol{R}$ for $\mathbf{S i}$ & Predictive equation \\
\hline Thalassionema nitzschioides & $-4.379^{* * * *}$ & -0.676 & -0.363 & 0.543 & $2.435^{*}$ & -0.426 & $\mathrm{TN}=-0.106 \mathrm{~T}+52.950 \mathrm{~N}_{2}+4.229$ \\
Pseudo-nitzschia delicatissima & $3.803^{* * *}$ & 1.151 & 0.080 & $4.465^{* * *}$ & 1.528 & -1.512 & $\mathrm{PD}=34.441 \mathrm{~N}_{1}+0.169 \mathrm{~T}-4.351$ \\
$\quad$ Paralia sulcata & -0.839 & 0.188 & 0.500 & $2.827^{* *}$ & -0.543 & 1.109 & $\mathrm{PS}=14.559 \mathrm{~N}_{1}-0.180$ \\
Prorocentrum micans & 0.329 & $2.506^{*}$ & -1.656 & 0.587 & 0.671 & $-5.205^{* * *}$ & $\mathrm{PM}=-5.880 \mathrm{Si}+1.090 \mathrm{~S}-34.940$ \\
Chaetoceros curvisetus & -0.493 & -0.139 & 0.262 & 0.086 & -0.785 & $4.062^{* * *}$ & $\mathrm{CC}=3.797 \mathrm{Si}-0.356$ \\
Total phytoplankton & -0.615 & $2.206^{*}$ & -0.099 & 0.599 & 0.155 & $3.852^{* * *}$ & $\mathrm{TP}=1.084 \mathrm{Si}+0.239 \mathrm{~S}-5.069$ \\
Species richness & 0.912 & -0.518 & 0.426 & 0.879 & 0.150 & 1.286 & $\mathrm{~ns}$ \\
Species diversity & 1.444 & 0.735 & -0.357 & 1.511 & 0.027 & 0.982 & $\mathrm{~ns}$ \\
\hline
\end{tabular}

Note: $T$, temperature; $S$, salinity; $P$, phosphate; $N_{1}$, nitrate; $N_{2}$, nitrite; Si, silicate. $*: P<0.05$; **: $P<0.01$; ***: $P<0.001 ; n s, n o t$ significant. 
semi-enclosed bay (Fig. 1). The seawater exchange rate between inshore and offshore areas was lower near NPP II than near NPP I and the difference may affect the thermal discharge dispersion efficiency (Fig. 4). This is evidenced by a clear temperature spatial pattern, where the average temperature was always higher $\left(\mathrm{ca} 0.5-1.5^{\circ} \mathrm{C}\right)$ in the waters off NPPII than NPPI (Fig. 2a). The higher temperature usually caused an increase in phytoplankton abundance in inshore waters at NPP II during the warm periods (Fig. 5).

A clear seasonal structure in which stations in the same season were clustered together was derived from the MDS using phytoplankton species composition analysis (Fig. 7). The dominant phytoplankton species in different seasons were usually dissimilar (Table 2). With the MDS ordination we found significant temporal differences between the phytoplankton communities off NPP I and NPP II in winter and summer. Among the five predominant phytoplankton species, $T$. nitzschioides, a cosmopolitan diatom in neritic as well as oceanic waters (Marshall 1982), usually constituted over $20 \%$ of the total phytoplankton cells and was the most abundant species in each season except in summer. In the present study, it was significantly negatively correlated with temperature; and usually had higher abundances in the NPP I intake during the cold period (Table 4, Fig. 6a). This finding is consistent with a previous study in this area by Lo et al. (2004).

$P$. delicatissima, a very common species in this area, showed a significantly higher abundance during the warm period (Fig. 6b). This species has a wide distribution range in both oceanic and coastal waters (Hasle et al. 1996; Hasle and Syvertsen 1997; Hasle 2002). At times it becomes the dominant diatom species among marine plankton, for example in the North Atlantic (Hasle et al. 1996). According to a study by Patrick (1969), the diatom genus Pseudo-nitzschia has great ability to tolerate thermal stress. In the Gulf of Naples (Mediterranean Sea), P. delicatissima often shows a second abundance peak in autumn when the water temperature is higher than in spring and the water column is still stratified (Orsini et al. 2004; Ribera d'Alcalà et al. 2004). In this study it was the most abundant species off both NPPs in summer and highly abundant in the NPP II outlet in spring. Furthermore, it was significantly positively correlated with temperature (Table 4). However, our results were inconsistent with those of Lo et al. (2004) who concluded that $P$. delicatissima was the most dominant species during the cooler seasons.

The third most abundant species, P. sulcata, has a wide distribution and is often found in temperate brackish to marine planktonic and benthic waters, in both littoral and sublittoral zones (McQuoid and Nordberg 2003a, b). Its abundance decreased rapidly in this study with increasing temperature and increased with high nitrate concentrations (Table 4, Fig. 6c). A laboratory study by Ramamurthy and Krishnamoorthy (1965) reported that the optimum temperature for $P$. sulcata growth and cell division in cultures was $17^{\circ} \mathrm{C}$, which supports our results that $P$. sulcata prefers the cooler season. At Helgoland Roads, North Sea, Gebühr et al. (2009) also observed that $P$. sulcata occurred mainly in late autumn and winter from 1962 - 1996, but since 1997 it has been found throughout the year. The changes in temperature, light, and nutrient conditions were suggested to be responsible for a shift in the ecological niche of $P$. sulcata. On the other hand, in Scottish isolated basins an opposite result was reported by Zong (1997), where P. sulcata was abundant during warmer periods and disappeared when the nutrient supply, water chemistry, vegetation and sediment characteristics were changed due to cooler conditions.

The dinoflagellate $P$. micans is one of the most common species in the study area and is cosmopolitan in cold to warm waters. This species is abundant and most frequently seen among its congeners. In addition, it usually blooms extensively, but is considered harmless as it causes non-toxic red tides. Guimarães and Rörig (2004) compared the growth response of $P$. micans to three salinity values $(25,30$, and 34 ) and found that this species grew faster at salinity 30 and slower at salinity 25 . In a semi-enclosed Mediterranean lagoon (Tunisia, SW Mediterranean), Sahraoui et al. (2013) found that $P$. micans seemed more likely to proliferate in saline waters with high concentrations of inorganic nutrients (nitrate, ammonia, and phosphate). In the present study, $P$. micans occurred mainly in spring and had a positive correlation with salinity (Table 4, Fig. 6d). We found that the average salinity in NPP waters in spring was about 0.5 higher than during the other seasons (Fig. 2). Thus, we believe that salinity may be an important factor that affects the P. micans distribution in NPP waters.

Chaetoceros is the most diverse and widespread genus of marine planktonic diatoms. In this study, $C$. curvisetus, the $5^{\text {th }}$ dominant species, was common in the NPP coastal waters (also observed by Lo et al. 2004). Chiang et al. (1999) investigated the spring distribution of diatom assemblages in the ECS and found that this species was a dominant species in the coastal assemblage. Lee et al. (2001) reported the predominance of $C$. curvisetus in the surface waters of all samples in their collection from the coastal waters off Tongyeong in Korea during the cooler season in October. In addition, in the marine Lake Rogoznica (eastern Adriatic coast) Burić et al. (2009) found that $C$. curvisetus appeared during spring when higher nitrate concentrations were present. A similar phenomenon was also observed in the present study (Fig. 6e).

\subsection{Preliminary Observations on the Effect of Thermal Discharges on Phytoplankton Communities}

The impact of thermal discharge from the nuclear power plant may cause some effects on the phytoplankton community. In the present study we noted a most remarkable difference in phytoplankton species composition between the intake and outlet waters (Table 3). It was reported that 
in the outlet area of power plants the seawater temperature increased about $8-12^{\circ} \mathrm{C}$ in temperate zones (Bamber 1995) and $6-10^{\circ} \mathrm{C}$ in tropical areas (Martínez-Arroyo et al. 2000; Poornima et al. 2006). In the subtropical Daya Bay in China, Li et al. (2011) also suggested that the seawater temperature at the outfall station was significantly higher than in the surrounding water, by as much as $5.6^{\circ} \mathrm{C}$, and increased by $6.8^{\circ} \mathrm{C}$ during the 23 -year study period. Although we did not have sufficient temperature data on the NPP outlet, temperature records for NPP II outlet and intake during 2001 - 2003 were available from two previous studies. Chuang et al. (2009) measured the outlet and intake seawater temperature for NPP II trimonthly and found that the average temperature in the outlet was usually $8-11^{\circ} \mathrm{C}$ higher than that in the intake. Shiah et al. (2006) reported a difference of about $10^{\circ} \mathrm{C}$ between the outlet (higher) and intake (lower) waters of this power plant.

Robust standards for thermal discharges into transitional and coastal waters are still missing (Wither et al. 2012). Do elevated seawater temperatures really affect phytoplankton growth? In an earlier laboratory study on marine phytoplankton, Hirayama and Hirano (1970) found that Chlamydomonas sp. and Skeletonema costatum (Greville) Cleve 1873 were not damaged severely when the seawater temperature was raised to $35-40^{\circ} \mathrm{C}$. Sellner et al. (1984) reported that an increase of $6^{\circ} \mathrm{C}$ affected the $\mathrm{C}$-fixation of certain microflagellates, but not dinoflagellates and diatoms. In a laboratory study using diatoms isolated from the Madras Atomic Power Station in Kalpakkam, India, Rajadurai et al. (2005) concluded that acute exposure to temperatures as high as $42^{\circ} \mathrm{C}$ did not significantly affect the growth of diatoms. These studies were confirmed by our results that the thermal discharge effect from the NPPs on the abundance and diversity of phytoplankton was minimal.

We expect that thermal discharge may affect the species composition of phytoplankton communities between the outlet and intake regions, as reported by Poornima et al. (2005) and Chuang et al. (2009). Similarly, Li et al. (2011) found that the contribution of diatoms and dinoflagellates to the total phytoplankton population showed significant correlation with temperature, negative for diatoms, while positive for dinoflagellates. In the present study the species composition showed $46-100 \%$ and $58-71 \%$ differences between the outlet and intake of NPP I and NPP II for each season, respectively (calculated by similarity indices, data not shown). We speculate that the change in phytoplankton species composition could be due to a difference in phytoplankton species suitability to thermal stress. The phytoplankton population was heavily dominated by diatoms in the present study (Table 2). Patrick (1969) reported that the dominant diatom genera, Nitzschia, Navicula, and Achnanthes, in the periphyton of the outlet region were similar to those of freshwater periphyton that were tolerant to high temperatures. By contrast, the diatoms, Mastogloia,
Diploneis, Cocconeis, and Epithemia, did not tolerate high temperatures and were absent from the outlet region but occurred only in the intake region of NPP II (Chuang et al. 2009). Similar phenomena were also noted by the present study. The elevated temperature in the NPP outlet area was favorable for the growth of diatoms, R. arcuatum, P. delicatissima, and Melosira sulcata (Ehrenberg) Kützing 1844 and dinoflagellate, $P$. micans, which had a high abundance during the specific season (Table 3 ).

In conclusion, seasonal differences in phytoplankton abundance became evident in the study area. However, no significant differences in species richness and species diversity were observed. In general, mean abundance, and phytoplankton species richness were higher in the NPP I waters than in NPP II waters. According to the preliminary observation we suggest that the thermal effluents may affect the phytoplankton species composition between the outlet and intake regions. This study provides basic knowledge on the distributional patterns of phytoplankton off two coastal nuclear power plants, essential information required to further understand the ecological impact caused by thermal discharge. More research is still required to observe such community effects caused by the thermal effluent.

Acknowledgements We thank the crew of the Ocean Research II for their assistance in collecting phytoplankton samples and other environmental data. We are grateful to Prof. C.-T. Shih of National Taiwan Ocean University for his critical review and valuable comments on the manuscript. We also thank two Anonymous Reviewers for their constructive input and improvement of the manuscript. This work was supported by grants from Taiwan Power Company, the Ministry of Science and Technology (NSC982611-M 110-002), and the Ministry of Education (Kuroshio Project) of the Republic of China.

\section{REFERENCES}

Allison, P. D., 1998: Multiple Regression: A Primer, Pine Forge Press, 202 pp.

Bamber, R. N., 1995: The influence of rising background temperature on the effects of marine thermal effluents. J. Therm. Biol., 20, 105-110, doi: 10.1016/03064565(94)00038-K. [Link]

Bruland, K. W., E. L. Rue, G. J. Smith, and G. R. DiTullio, 2005: Iron, macronutrients and diatom blooms in the Peru upwelling regime: Brown and blue waters of Peru. Mar. Chem., 93, 81-103, doi: 10.1016/J. MARCHEM.2004.06.011. [Link]

Burić, Z., K. C. Mihalić, I. Cetinić, I. Ciglenečki, M. Carić, D. Viličić, and B. Ćosović, 2009: Occurrence of the rare microflagellates Prorocentrum arcuatum Issel and Hermesinum adriaticum Zacharias in the marine Lake Rogoznica (eastern Adriatic coast). Acta. Adriat., 50, 
31-44.

Chiang, K. P., Y. T. Chen, and G. C. Gong, 1999: Spring distribution of diatom assemblages in the East China Sea. Mar. Ecol. Prog. Ser., 186, 75-86, doi: 10.3354/ meps186075. [Link]

Choi, D. H., J. S. Park, C. Y. Hwang, S. H. Huh, and B. C. Cho, 2002: Effects of thermal effluents from a power station on bacteria and heterotrophic nanoflagellates in coastal waters. Mar. Ecol. Prog. Ser., 229, 1-10, doi: 10.3354/meps229001. [Link]

Chuang, Y. L., H. H. Yang, and H. J. Lin, 2009: Effects of a thermal discharge from a nuclear power plant on phytoplankton and periphyton in subtropical coastal waters. J. Sea Res., 61, 197-205, doi: 10.1016/j. seares.2009.01.001. [Link]

Clarke, K. R. and R. M. Warwick, 2001: Change in Marine Communities: An Approach to Statistical Analysis and Interpretation, PRIMER-E Ltd., Plymouth, UK.

Cottingham, K. L., 1999: Nutrients and zooplankton as multiple stressors of phytoplankton communities: Evidence from size structure. Limnol. Oceanogr., 44, 810827, doi: 10.4319/lo.1999.44.3_part_2.0810. [Link]

Cox, T. F. and M. A. A. Cox, 1994: Multidimensional Scaling, Taylor \& Francis, 216 pp.

Davison, I. R., 1991: Environmental effects on algal photosynthesis: Temperature. J. Phycol., 27, 2-8, doi: 10.1111/j.0022-3646.1991.00002.x. [Link]

Dunn, O. J. and V. Clark, 1974: Applied Statistics: Analysis of Variance and Regression, John Wiley \& Sons Inc., $387 \mathrm{pp}$.

Gebühr, C., K. H. Wiltshire, N. Aberle, J. E. E. van Beusekom, and G. Gerdts, 2009: Influence of nutrients, temperature, light and salinity on the occurrence of Paralia sulcata at Helgoland Roads, North Sea. Aquat. Biol., 7, 185-197, doi: 10.3354/ab00191. [Link]

Grasshoff, K., M. Ehrhardt, K. Kremling, and T. Almgren, 1983: Methods of Seawater Analysis, Verlag Chemie, $419 \mathrm{pp}$.

Guimarães, S. C. P. and L. R. Rörig, 2004: Salinity effect in growth of Prorocentrum micans Ehrenberg and Prorocentrum cf. obtusum Ostenfeld dinoflagelates isolateds from Santa Catarina coast zone, Brazil. Rev. Estud. de Biol., 26, 29-36. (in Latin)

Hasle, G. R., 2002: Are most of the domoic acid-producing species of the diatom genus Pseudo-nitzschia cosmopolites? Harmful Algae, 1, 137-146, doi: 10.1016/ S1568-9883(02)00014-8. [Link]

Hasle, G. R. and E. E. Syvertsen, 1997: Marine diatoms. In: Tomas, C. R. (Ed.), Identifying Marine Phytoplankton, Academic Press, San Diego, 5-385, doi: 10.1016/ B978-012693018-4/50004-5. [Link]

Hasle, G. R., C. B. Lange, and E. E. Syvertsen, 1996: A review of Pseudo-nitzschia, with special reference to the Skagerrak, North Atlantic, and adjacent waters. $\mathrm{Hel}$ - goländer Meeresunters., 50, 131-175, doi: 10.1007/ BF02367149. [Link]

Hecky, R. E. and P. Kilham, 1988: Nutrient limitation of phytoplankton in freshwater and marine environments: A review of recent evidence on the effects of enrichment. Limnol. Oceanogr., 33, 796-822.

Heip, C. H. R., N. K. Goosen, P. M. J. Herman, J. Kromkamp, J. J. Middelburg, and K. Soetaert, 1995: Production and consumption of biological particles in temperate tidal estuaries. Oceanogr. Mar. Biol., 33, 1-149.

Hirayama, K. and R. Hirano, 1970: Influences of high temperature and residual chlorine on marine phytoplankton. Mar. Biol., 7, 205-213, doi: 10.1007/BF00367490. [Link]

Hung, T. C., C. C. Huang, and K. T. Shao, 1998: Ecological survey of coastal water adjacent to nuclear power plants in Taiwan. Chem. Ecol., 15, 129-142, doi: 10.1080/02757549808037625. [Link]

Jan, S., D. D. Sheu, and H. M. Kuo, 2006: Water mass and throughflow transport variability in the Taiwan Strait. J. Geophys. Res., 111, C12012, doi: 10.1029/2006JC003656. [Link]

Jiang, Z. B., J. N. Zeng, Q. Z. Chen, Y. J. Huang, Y. B. Liao, X. Q. Xu, and P. Zheng, 2009: Potential impact of rising seawater temperature on copepods due to coastal power plants in subtropical areas. J. Exp. Mar. Biol. Ecol.,368, 196-201, doi: 10.1016/j.jembe.2008.10.016. [Link]

Jordan, R. A., P. G. Martin, and C. E. Sutton, 1983: Selective effects of phytoplankton entrainment at the Surry Power Plant, James River, Virginia. Hydrobiologia, 106, 253-261, doi: 10.1007/BF00008124. [Link]

Lardicci, C., F. Rossi, and F. Maltagliati, 1999: Detection of thermal pollution: Variability of benthic communities at two different spatial scales in an area influenced by a coastal power station. Mar. Pollut. Bull., 38, 296-303, doi: 10.1016/S0025-326X(98)00149-0. [Link]

Lee, J. H., J. Chae, W. R. Kim, S. W. Jung, and J. M. Kim, 2001: Seasonal variation of phytoplankton and zooplankton communities in the coastal waters off Tongyeong in Korea. Ocean Polar Res., 23, 245-253.

Li, T., S. Liu, L. Huang, H. Huang, J. Lian, Y. Yan, and S. Lin, 2011: Diatom to dinoflagellate shift in the summer phytoplankton community in a bay impacted by nuclear power plant thermal effluent. Mar. Ecol. Prog. Ser., 424, 75-85, doi: 10.3354/meps08974. [Link]

Liu, K. K., G. C. Gong, C. Z. Shyu, S. C. Pai, C. L. Wei, and S. Y. Chao, 1992: Response of Kuroshio upwelling to the onset of the northeast monsoon in the sea north of Taiwan: Observations and a numerical simulation. J. Geophys. Res., 97, 12511-12526, doi: 10.1029/92JC01179. [Link]

Lo, W. T., J. J. Hwang, P. K. Hsu, H. Y. Hsieh, Y. Y. Tu, T. H. Fang, and J. S. Hwang, 2004: Seasonal and spatial 
distribution of phytoplankton in the waters off Nuclear Power plants, north of Taiwan. J. Mar. Sci. Technol., 12, 372-379.

Lobban, C. S., D. J. Chapman, and B. P. Kremer, 1988: Experimental Phycology: A Laboratory Manual, Cambridge University Press, Cambridge, 320 pp.

Marshall, H. G., 1982: The composition of phytoplankton within the Chesapeake Bay plume and adjacent waters off the Virginia coast, U.S.A. Estuar. Coast. Shelf Sci., 15, 29-43, doi: 10.1016/0272-7714(82)90034-8. [Link]

Martínez-Arroyo, A., S. Abundes, M. E. González, and I. Rosas, 2000: On the influence of hot-water discharges on phytoplankton communities from a coastal zone of the Gulf of Mexico. Water Air Soil Pollut., 119, 209230, doi: 10.1023/A:1005161309609. [Link]

McQuoid, M. R. and K. Nordberg, 2003a: Environmental influence on the diatom and silicoflagellate assemblages in Koljö Fjord (Sweden) over the last two centuries. Estuaries, 26, 927-937, doi: 10.1007/BF02803351. [Link]

McQuoid, M. R. and K. Nordberg, 2003b: The diatom Paralia sulcata as an environmental indicator species in coastal sediments. Estuar. Coast. Shelf Sci., 56, 339354, doi: 10.1016/S0272-7714(02)00187-7. [Link]

Orsini, L., G. Procaccini, D. Sarno, and M. Montresor, 2004: Multiple rDNA ITS-types within the diatom Pseudo-nitzschia delicatissima (Bacillariophyceae) and their relative abundances across a spring bloom in the Gulf of Naples. Mar. Ecol. Prog. Ser., 271, 87-98, doi: 10.3354/meps271087. [Link]

Patrick, R., 1969: Some effects of the temperature on freshwater algae. In: Krenkel, P. A. and F. L. Parker (Eds.), Biological Aspects of Thermal Pollution, Vanderbilt University Press, Nashville, 161-185.

Pielou, E. C., 1984: The Interpretation of Ecological Data: A Primer on Classification and Ordination, John Wiley \& Sons, $263 \mathrm{pp}$.

Poornima, E. H., M. Rajadurai, T. S. Rao, B. Anupkumar, R. Rajamohan, S. V. Narasimhan, V. N. R. Rao, and V. P. Venugopalan, 2005: Impact of thermal discharge from a tropical coastal power plant on phytoplankton. J. Therm. Biol., 30, 307-316, doi: 10.1016/j. jtherbio.2005.01.004. [Link]

Poornima, E. H., M. Rajadurai, V. N. R. Rao, S. V. Narasimhan, and V. P. Venugopalan, 2006: Use of coastal waters as condenser coolant in electric power plants: Impact on phytoplankton and primary productivity. J. Therm. Biol., 31, 556-564, doi; 10.1016/j. jtherbio.2006.05.009. [Link]

Rajadurai, M., E. H. Poornima, S. V. Narasimhan, V. N. R. Rao, and V. P. Venugopalan, 2005: Phytoplankton growth under temperature stress: Laboratory studies using two diatoms from a tropical coastal power station site. J. Therm. Biol., 30, 299-305, doi: 10.1016/j. jtherbio.2005.01.003. [Link]

Ramamurthy, V. D. and K. Krishnamoorthy, 1965: On the culture of the diatom Melosira sulcata (Ehr.) kutzing. Proc. Indian Acad. Sci. B, 62, 25-31, doi: 10.1007/ BF03051079. [Link]

Ribera d'Alcalà, M., F. Conversano, F. Corato, P. Licandro, O. Mangoni, D. Marino, M. G. Mazzocchi, M. Modigh, M. Montresor, M. Nardella, V. Saggiomo, D. Sarno, and A. Zingone, 2004: Seasonal patterns in plankton communities in a pluriannual time series at a coastal Mediterranean site (Gulf of Naples): An attempt to discern recurrences and trends. Sci. Mar., 68, 65-83, doi: 10.3989/scimar.2004.68s165. [Link]

Sahraoui, I., D. Bouchouicha, H. H. Mabrouk, and A. S. Hlaili, 2013: Driving factors of the potentially toxic and harmful species of Prorocentrum Ehrenberg in a semi-enclosed Mediterranean lagoon (Tunisia, SW Mediterranean). Mediterr. Mar. Sci., 14, 353-362, doi: 10.12681/mms.338. [Link]

Sellner, K. G., M. E. Kachur, and L. Lyons, 1984: Alterations in carbon fixation during power plant entrainment of estuarine phytoplankton. Water Air Soil Pollut., 21, 359-374, doi: 10.1007/BF00163636. [Link]

Shannon, C. E. and W. Weaver, 1963: The Mathematical Theory of Communication, University of Illinois Press, Chicago.

Shiah, F. K., Y. Y. Tu, H. S. Tsai, S. J. Kao, and S. Jan, 2005: A case study of system and planktonic responses in a subtropical warm plume receiving thermal effluents from a power plant. Terr. Atmos. Ocean. Sci., 16, 513-528.

Shiah, F. K., T. H. Wu, K. Y. Li, S. J. Kao, Y. F. Tseng, J. L. Chung, and S. Jan, 2006: Thermal effects on heterotrophic processes in a coastal ecosystem adjacent to a nuclear power plant. Mar. Ecol. Prog. Ser., 309, 55-65, doi: 10.3354/meps309055. [Link]

Sørensen, T. J., 1948: A method of establishing groups of equal amplitude in plant sociology based on similarity of species and its application to analyses of the vegetation on Danish commons. Biol. Skr., 5, 1-34.

Strickland, J. D. H. and T. R. Parsons, 1972: A Practical Handbook of Seawater Analysis, Fisheries Research Board of Canada, Ottawa, $310 \mathrm{pp}$.

Suresh, K., M. S. Ahamed, G. Durairaj, and K. V. K. Nair, 1995: Environmental physiology of the mole crab Emerita asiatica, at a power plant discharge area on the east coast of India. Environ. Pollut., 88, 133-136, doi: 10.1016/0269-7491(95)91436-O. [Link]

Teixeira, T. P., L. M. Neves, and F. G. Araújo, 2009: Effects of a nuclear power plant thermal discharge on habitat complexity and fish community structure in Ilha Grande Bay, Brazil. Mar. Environ. Res., 68, 188-195, doi: 10.1016/j.marenvres.2009.06.004. [Link]

Wither, A., R. Bamber, S. Colclough, K. Dyer, M. Elliott, 
P. Holmes, H. Jenner, C. Taylor, and A. Turnpenny, 2012: Setting new thermal standards for transitional and coastal (TraC) waters. Mar. Pollut. Bull., 64, 15641579, doi: 10.1016/j.marpolbul.2012.05.019. [Link]

Yang, Y., Z. Wang, M. Pan, and N. Jiao, 2002: Zooplankton community structure of the sea surface microlayer near nuclear power plants and marine fish culture zones in Daya Bay. Chin.J.Oceanol.Limnol., 20, 129-134, doi: 10.1007/BF02849649. [Link]

Zong, Y. 1997: Implications of Paralia Sulcata abundance in Scottish isolation basins. Diatom Res., 12, 125-150, doi: 10.1080/0269249X.1997.9705407. [Link] 